OnLine Journal of Biological Sciences 8 (1): 1-9, 2008

ISSN 1608-4217

(C) 2008 Science Publications

\title{
Trace Metal Effect on Hydrogen Production Using C.acetobutylicum
}

\author{
${ }^{1}$ Hisham Alshiyab, ${ }^{2}$ Mohd Sahaid Kalil, ${ }^{1}$ Aidil Abdul Hamid, ${ }^{1}$ Wan Mohtar Wan Yusoff \\ ${ }^{1}$ Faculty of Science and Technology, School of Bioscience and Biotechnology, \\ ${ }^{2}$ Faculty of engineering, Department of Chemical and Process Engineering \\ Universiti Kebangsaan Malaysia, 43600 UKM Bangi Selangor, Malaysia
}

\begin{abstract}
This study was carried out to study the effect of trace metal addition for hydrogen production The results show that this bacterial need a selected nutrient with selected concentration. The optimum parameters for cultivation were at initial $\mathrm{pH}$ of 7.0 and temperature of $30^{\circ} \mathrm{C}$. Trace metal addition to the new medium showed that only iron enhanced the $\mathrm{H}_{2}$ yield. The results showed that $25 \mathrm{mgL}^{-1} \mathrm{FeSO}_{4} \cdot 7 \mathrm{H}_{2} \mathrm{O}$ enhanced the hydrogen yield from $391 \mathrm{mLg}^{-1}$ to $408 \mathrm{mLg}^{-1}$ glucose utilized with biomass concentration of $1.38 \mathrm{gL}^{-1}$. $\mathrm{Y}_{\mathrm{P} / \mathrm{X}}$ of $292 \mathrm{mLg}^{-1} \mathrm{~L}^{-1}$, $\mathrm{Y}_{\mathrm{X} / \mathrm{S}}$ of 0.276 and $\mathrm{Y}_{\mathrm{H} 2 / \mathrm{s}}$ of 0.0364 , gave the maximum hydrogen productivity of $81.6 \mathrm{~mL} \mathrm{~L}^{-1} \mathrm{~h}^{-1}$. Magnesium and calcium addition were better for growth and not for hydrogen production. Biomass concentration increases as trace metal increases in the fermentation medium. The highest biomass concentration was $1.65 \mathrm{gL}^{-1}$ at $1000 \mathrm{mgL}^{-1}$ $\mathrm{FeSO}_{4} \cdot 7 \mathrm{H}_{2} \mathrm{O}, 1.47 \mathrm{gL}^{-1}$ at $1000 \mathrm{mgL}^{-1} \mathrm{MgSO}_{4} \cdot 7 \mathrm{H}_{2} \mathrm{O}$ and $1.73 \mathrm{gL}^{-1}$ at $500 \mathrm{mgL}^{-1} \mathrm{CaCl}_{2} \cdot 2 \mathrm{H}_{2} \mathrm{O}$, suggested that all trace metal are necessary for biomass production.
\end{abstract}

Key words: Biohydrogen, batch fermentation, glucose, trace metal

\section{INTRODUCTION}

Fermentative $\mathrm{H}_{2}$ bio-production processes are not only environment friendly, but also lead to open a new avenue for the utilization of renewable energy resources which are inexhaustible ${ }^{[1]}$. The fermentative $\mathrm{H}_{2}$ production is of higher capacity and lower cost than photosynthetic. The purpose of biohydrogen production studies is to develop commercially practical $\mathrm{H}_{2}$ production processes through modern biotechnology. In this case, the critical factor is to find the means to enhance the hydrogen yield. Since nutrient availability and metabolites accumulation may often result in growth limitation and consequent inhibition of hydrogen production, there is need to obtain the precise quantification of the extent to which each phenomenon contributes to overall growth and hydrogen production behavior.

Bio-hydrogen production requires essential micronutrients for bacterial metabolism during fermentation. Sodium, magnesium, zinc and iron are all important trace metals affecting hydrogen production. Among them iron is an important nutrient element to form hydrogenase or other enzymes which almost all biohydrogen production needs fundamentally ${ }^{[2]}$. According to literature, magnesium ion is an activator of many kinases and synthetases. In cytoplasm there are
10 kinds of enzymes involved in glycolysis and most of these enzymes need magnesium ion as cofactors such as hexokinase, phosphofructokinase, glyceraldehyde-3phosphate dehydrogenase and enolase, etc. ${ }^{[3]}$. Thus, the aim of this study was to study the effect of trace metal like Iron, Magnesium and Calcium addition on hydrogen production by fermentative bacterial C.acetobutylicum NCIMB13357.

\section{MATERIAL AND METHODS}

Microorganism and culture conditions: $C$. acetobutylicum NCIMB 13357 was purchased from a British culture collection, NCIMB Ltd. Scotland, UK. The bacterium was cultivated in anaerobic condition in Reinforced Clostridial Medium (RCM) for $24 \mathrm{~h}$ at $30^{\circ} \mathrm{C}$. Liquid medium of RCM was used for inoculum preparation. The growth of culture in RCM was monitored by measuring an optical density at $600 \mathrm{~nm}$ using a spectrophotometer. Only inoculum with Optical Density (OD) values greater than 0.4-0.6 after $18 \mathrm{~h}$. cultivation was used as inoculum. An inoculum of $10 \%$ $\mathrm{v} / \mathrm{v}$ was used throughout this study. Batch fermentation was carried out at a working volume of $100 \mathrm{~mL}$ in $500 \mathrm{~mL}$ rector bottles at $30^{\circ} \mathrm{C}$, each medium was seeded with a $10 \%$ inoculum inside anaerobic cabinet and sparged with nitrogen gas $(99.9 \%)$. All the bottles

Corresponding Author: Mohd Sahaid Kalil, Department of Chemical Engineering and Process, Faculty of Engineering, University Kebangsaan Malaysia, 43600 UKM-Bangi-Selangor-Malaysia Tel:+60387368616 
were tightly closed. The culture $\mathrm{pH}$ was not controlled during fermentation and the initial $\mathrm{pH}$ was fixed to 7.0 before sterilization process. To quantify $\mathrm{H}_{2}$, gas produced during fermentation was recorded at the end of its production. The evolved gas was collected in a gas collection inverted cylinder and the volume of evolved gas was measured at room temperature by the water displacement method Morimoto et $a l^{[4]}$ in a graduated cylinder that had been filled with water of $\mathrm{pH} 3$ or less in order to prevent dissolution of the gas components

Cultivation medium: New medium we formulated in our lab to be used for hydrogen production and for the bacterium species we used in this study have the following composition in $\left(\mathrm{g} \mathrm{L}^{-1}\right)$ : glucose (5), Yeast Extract (5), L-Cystine. $\mathrm{HCl}$ (1.0) and bacteriological agar (0.5). Batch experiments were conducted with $500 \mathrm{~mL}$ Scotch bottle with working volume of $100 \mathrm{~mL}$ (90\% culture medium and $10 \%$ inoculum). Different concentrations of trace metal were used to find out its effect on fermentative bacteria we used in this study, ranging from 0.0 to $1000 \mathrm{mgL}^{-1}$ for $\mathrm{FeSO}_{4} .7 \mathrm{H}_{2} \mathrm{O}$ and $\mathrm{MgSO}_{4} .7 \mathrm{H}_{2} \mathrm{O}$ and from 0.0 to $500 \mathrm{mgL}^{-1} 1$ for $\mathrm{CaCal}_{2} \cdot 2 \mathrm{H} 2 \mathrm{O}$. All of these data were the average (mean) of three trials.

Analytical methods: The gas composition was determined by gas chromatography (Shimadzu Co., Kyoto, GC-8A) under the following conditions: column: Porapack-Q, carrier gas: Nitrogen, flow rate: $33 \mathrm{~mL} \mathrm{~min}{ }^{-1}$, column temperature: $50^{\circ} \mathrm{C}$, injection temperature: $100^{\circ} \mathrm{C}$, detector temperature: $50^{\circ} \mathrm{C}$, detector: Thermal Conductivity Detector (TCD). The soluble glucose concentration was measured at the end of each batch experiment for the calculation of the amount of glucose consumed by DNS method modified by Miller ${ }^{[5]}$ using spectrophotometer (UV 1601 IPC, Shimadzu corporation- Japan) optical density $\left(\mathrm{OD}_{550 \mathrm{~nm}}\right)$. Individual batch experiments were observed until the hydrogen production from each bottle stopped. All of these data were the average (mean) of three trials.

\section{RESULTS AND DISCUSSION}

Effect of Iron: Gas analysis showed that produced gas has only two gases with $65 \%$ for $\mathrm{H}_{2}$ and the rest was for $\mathrm{CO}_{2}$. The results shown in Fig. 1 shown that the hydrogen yield was enhanced from $391-408 \mathrm{mLg}^{-1}$ glucose utilized, by addition of $25 \mathrm{mgL}^{-1} \mathrm{FeSO}_{4} \cdot 7 \mathrm{H}_{2} \mathrm{O}$ to the culture medium, then started to decrease for

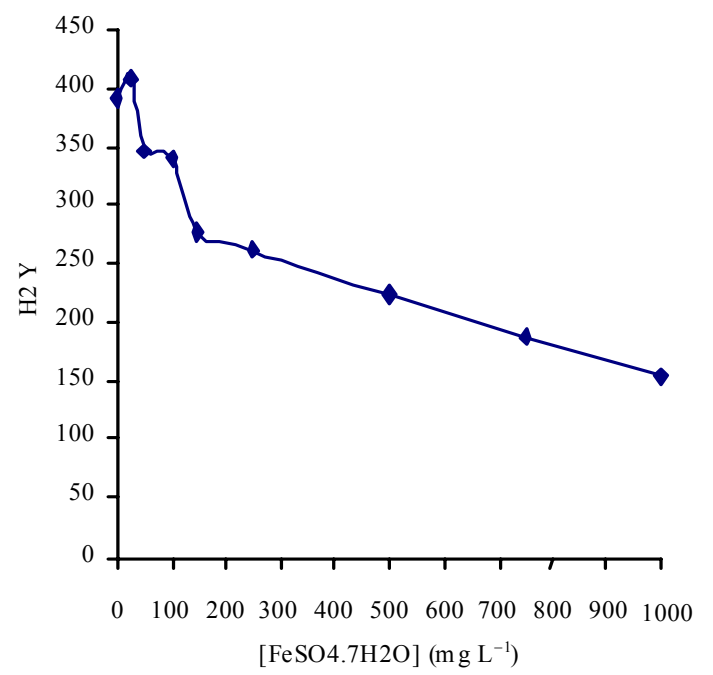

Fig. 1: Effect of [FeSO4.7H2O] addition on. $\mathrm{H} 2 \mathrm{Y}$ $\left(\mathrm{mLg}^{-1}\right.$ utilized)

Table 1: Results of $\mathrm{FeSO}_{4} \cdot 7 \mathrm{H}_{2} \mathrm{O}$ addition to fermentation medium on glucose consumption and $\mathrm{H}_{2} \mathrm{P} \quad\left(\mathrm{mLL}^{-1} \mathrm{~h}^{-1}\right)$ by C. acetobutylicum NCIMB 13357

\begin{tabular}{llll}
\hline$[\mathrm{FeSO} 4]\left(\mathrm{mgL}^{-1}\right)$ & $\mathrm{f} \mathrm{pH}$ & Glucose consumed $(\%)$ & $\mathrm{H}_{2} \mathrm{P}$ \\
\hline 0.0 & 4.45 & 87 & 77.5 \\
25 & 4.46 & 89 & 81.6 \\
50 & 4.45 & 90 & 70.0 \\
100 & 4.46 & 91 & 70.0 \\
150 & 4.48 & 93 & 58.5 \\
250 & 4.50 & 94 & 55.0 \\
500 & 4.57 & 95 & 61.0 \\
750 & 4.76 & 97 & 42.0 \\
1000 & 4.86 & 98 & 34.0 \\
\hline
\end{tabular}

[Glucose]: $5 \mathrm{gL}^{-1}$, Inoculum size $10 \%(\mathrm{v} / \mathrm{v}) \mathrm{I} \mathrm{pH}$. 7.0. Temperature $30^{\circ} \mathrm{C}$

further increase of iron addition to culture medium. From this observation, it was apparent that increasing the iron concentration in a culture medium more than the optimum concentration would decrease the $\mathrm{H}_{2}$ yield within the concentration range investigated. Iron supplementation up to $25 \mathrm{mgL}^{-1} \quad \mathrm{FeSO}_{4} \cdot 7 \mathrm{H}_{2} \mathrm{O}$, significantly enhanced the $\mathrm{H}_{2}$ yield by $4 \%$ over that produced by control $\left(0.0 \mathrm{mgL}^{-1}\right)$ (Table 1). Between 25 and $50 \mathrm{mgL}^{-1} \mathrm{FeSO}_{4} \cdot 7 \mathrm{H}_{2} \mathrm{O}$, further decreased of $\mathrm{H}_{2}$ yield from 408 to $347 \mathrm{mLg}^{-1}$ glucose utilized, which then decreased to $154 \mathrm{mLg}^{-1}$ glucose utilized at $1000 \mathrm{mgL}^{-1} \mathrm{FeSO}_{4} \cdot 7 \mathrm{H}_{2} \mathrm{O}$.

The results shown in Fig. 2 reveal that iron addition to fermentation medium have affected positively on two ways, the first was on hydrogen production by addition $25 \mathrm{mgL}^{-1}$ of $\mathrm{FeSO}_{4} \cdot 7 \mathrm{H}_{2} \mathrm{O}$ but was negatively for further increased and the second way was for biomass which was increased as the iron 
OnLine J. Biol. Sci., 8 (1): 1-9, 2008

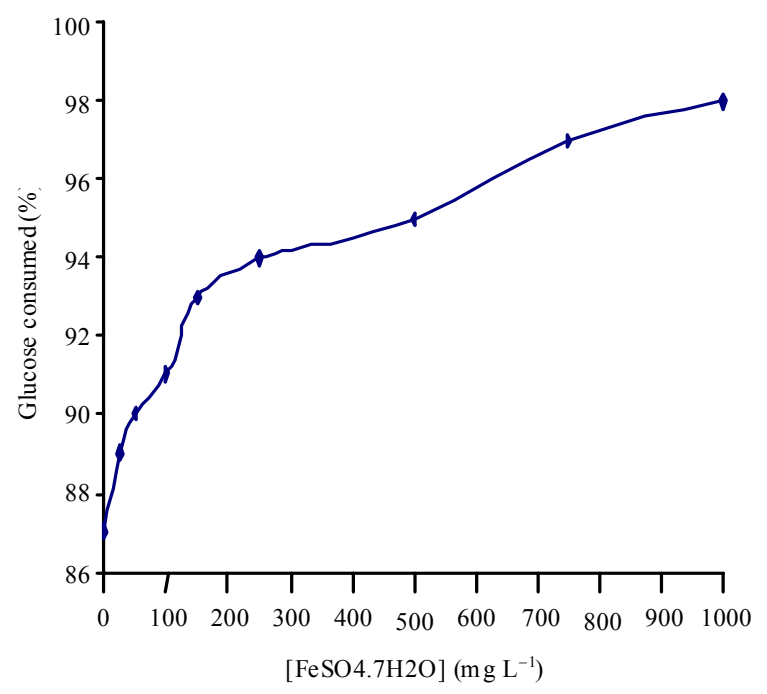

Fig. 2: Effect of [FeSO4.7H2O] addition on. Glucose consumption $(\%)$

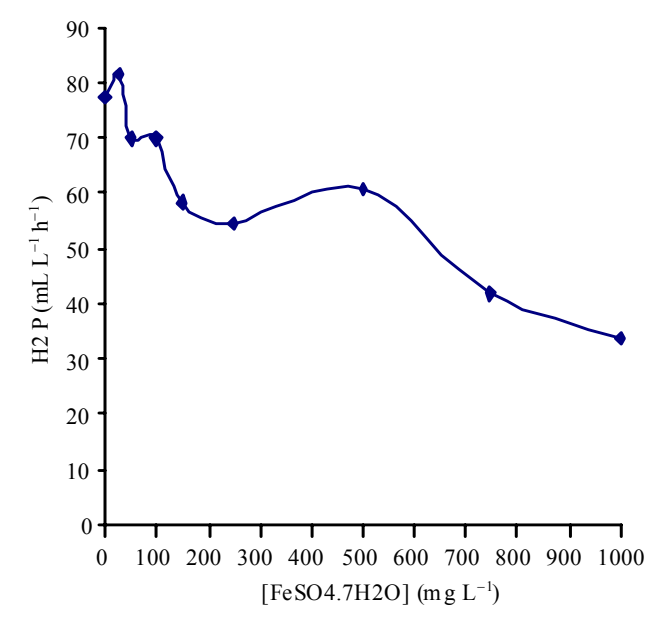

Fig. 3: Effect of [FeSO4.7H2O] addition on $\mathrm{H} 2 \mathrm{P}$

concentration increased and reached themaximum at $1000 \mathrm{mgL}^{-1}$ of $\mathrm{FeSO}_{4} \cdot 7 \mathrm{H}_{2} \mathrm{O}$. This increased in glucose consumption percentage was not enhanced the bacterial productivity but was used as shown in Fig. 4 for bacterial growth which was enhanced from 1.34$1.65 \mathrm{gL}^{-1}$ at $1000 \mathrm{mgL}^{-1}$. The increase of biomass was not shared with increasing of hydrogen production with only hydrogen yield of $154 \mathrm{mlg}^{-1}$ utilized glucose at $1000 \mathrm{mgL}^{-1}$. Final $\mathrm{pH}$ was depend on the produced biomass and as biomass increased, the bacterial metabolites increased, that would affect on bacterial productivity of hydrogen with maximum of $81.6 \mathrm{~mL} \mathrm{~L}^{-1} \mathrm{~h}^{-1}$ to decrease with increasing of $\mathrm{FeSO}_{4} .7 \mathrm{H}_{2} \mathrm{O}$ in culture medium as shown in Fig. 3,
Table 2: Results of $\mathrm{FeSO}_{4} .7 \mathrm{H}_{2} \mathrm{O}$ addition to fermentation medium on hydrogen production by C. acetobutylicum NCIMB 13357

\begin{tabular}{|c|c|c|c|c|c|c|}
\hline $\begin{array}{l}\mathrm{FeSO}_{4} \cdot 7 \mathrm{H}_{2} \mathrm{O} \\
\left(\mathrm{mgL}^{-1}\right)\end{array}$ & $\mathrm{Y}_{\mathrm{P} / \mathrm{S}}^{1}$ & $\mathrm{Y}_{\mathrm{P} / \mathrm{S}}^{2}$ & [Biomass] & $\mathrm{Y}_{\mathrm{P} / \mathrm{X}}$ & $\mathrm{Y}_{\mathrm{X} / \mathrm{S}}$ & $\mathrm{Y}_{\mathrm{H} 2 / \mathrm{S}}$ \\
\hline$\overline{0.0}$ & 340 & 391 & 1.34 & 292 & 0.27 & 0.034 \\
\hline 25 & 364 & 408 & 1.38 & 296 & 0.28 & 0.036 \\
\hline 50 & 312 & 347 & 1.38 & 251 & 0.28 & 0.031 \\
\hline 100 & 309 & 340 & 1.39 & 245 & 0.28 & 0.030 \\
\hline 150 & 258 & 277 & 1.41 & 196 & 0.28 & 0.024 \\
\hline 250 & 246 & 262 & 1.44 & 182 & 0.29 & 0.022 \\
\hline 500 & 214 & 225 & 1.53 & 147 & 0.31 & 0.020 \\
\hline 750 & 183 & 189 & 1.59 & 119 & 0.32 & 0.016 \\
\hline 1000 & 151 & 154 & 1.65 & 92 & 0.33 & 0.014 \\
\hline
\end{tabular}

$\mathrm{Y}_{\mathrm{P} / \mathrm{S}}^{1}\left(\mathrm{H}_{2} \mathrm{~mL} \mathrm{~g}^{-1}\right.$ glucose supplied) $\left(\mathrm{mLg}^{-1)}\right), \mathrm{Y}_{\mathrm{P} / \mathrm{S}}^{2}\left(\mathrm{mLg}^{-1}\right)$ (Utilized): $\left(\mathrm{H}_{2} \mathrm{~mL} \mathrm{~g}^{-1}\right.$ glucose utilized), [Biomass] $\left(\mathrm{gL}^{-1}\right)$. Biomass production $\mathrm{g} \mathrm{L}^{-1}$ culture, $\mathrm{Y}_{\mathrm{P} / \mathrm{X}}\left(\mathrm{mLg}^{-1} \mathrm{~L}^{-1}\right)$ : $\left(\mathrm{H}_{2} \mathrm{~mL} \mathrm{~g}^{-1}\right.$ Biomass $\left.\mathrm{L}^{-1}\right), \mathrm{Y}_{\mathrm{X} / \mathrm{S}}$ : (Biomass production per g glucose supplied), $\mathrm{Y}_{\mathrm{H} 2 / \mathrm{s}}$ ( conversion of $\mathrm{H}_{2}$ $(\mathrm{mL})$ to $\mathrm{H}_{2}(\mathrm{~g}) \mathrm{g}^{-1}$ glucose utilized) [Glucose] $.5 \mathrm{gL}^{-1}$, inoculum size $10 \%(\mathrm{v} / \mathrm{v}), \mathrm{I} \mathrm{pH} .7 .0$, Temperature $30^{\circ} \mathrm{C}$

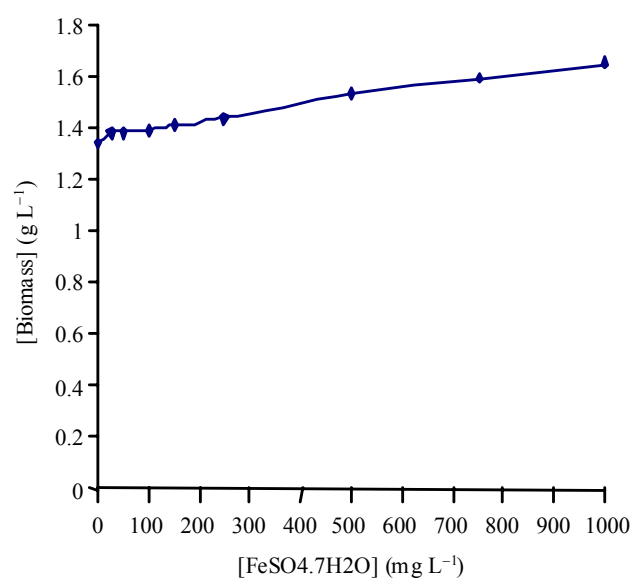

Fig. 4: Effect of [FeSO4.7H2O] addition on. [Biomass]

suggested that the iron concentration adversely affect on the bacterial metabolism. These results showed that even a small amount of iron greatly affected production and that the major effect of additional iron was to enhance the rate of production. It's well-known that iron is an indispensable element for bacterial multiplication. Undoubtedly, an appropriate amount of iron is beneficial to increasing the activity of bacteria.

Obtained data shown in Table 1 and 2 were used to calculate different yields like $\mathrm{Y}_{\mathrm{P} / \mathrm{X}}\left(\mathrm{mLg}^{-1} \mathrm{~L}^{-1}\right)$ : $\left(\mathrm{H}_{2} \mathrm{~mL} \mathrm{~g}^{-1}\right.$ Biomass $\left.\mathrm{L}^{-1}\right), \mathrm{Y}_{\mathrm{X} / \mathrm{S}}$ : (Biomass production per g glucose supplied) and $\mathrm{Y}_{\mathrm{H} 2 / \mathrm{s}}$ (conversion of $\mathrm{H}_{2}$ $(\mathrm{mL})$ to $\mathrm{H}_{2}(\mathrm{~g})$ per g glucose utilized). These results showed that increasing the iron concentration affect inversely on hydrogen production if used more than the proper concentration and was better for bacterial biomass suggested that the effect was related on the enzymes responsible for hydrogen evolution. 
OnLine J. Biol. Sci., 8 (1): 1-9, 2008

Table 3: Results of $\mathrm{MgSO}_{4} .7 \mathrm{H}_{2} \mathrm{O}$ addition to fermentation medium on glucose consumption (\%) and $\mathrm{H}_{2} \mathrm{P}\left(\mathrm{mLL}^{-1} \mathrm{~h}^{-1}\right)$ by $C$. acetobutylicum NCIMB 13357

\begin{tabular}{llll}
$\begin{array}{lll}{\left[\mathrm{MgSO}_{4} .7 \mathrm{H}_{2} \mathrm{O}\right]} \\
\left(\mathrm{mgL}^{-1}\right)\end{array}$ & $\mathrm{f} \mathrm{pH}$ & Glucose consumed $(\%)$ & $\mathrm{H}_{2} \mathrm{P}$ \\
\hline 50 & 4.50 & 89 & 52 \\
100 & 4.51 & 90 & 52 \\
200 & 4.50 & 91 & 56 \\
500 & 4.48 & 94 & 65 \\
750 & 4.52 & 96 & 53 \\
1000 & 4.54 & 98 & 42 \\
\hline
\end{tabular}

[Glucose] $5 \mathrm{gL}^{-1}$, inoculum size $10 \%(\mathrm{v} / \mathrm{v}), \mathrm{I} \mathrm{pH} .7 .0$, Temp $30^{\circ} \mathrm{C}$

Table 4: Results of $\mathrm{MgSO}_{4} .7 \mathrm{H}_{2} \mathrm{O}$ addition to fermentation medium on hydrogen production by C. acetobutylicum NCIMB 13357

$\left[\mathrm{MgSO}_{4} .7 \mathrm{H}_{2} \mathrm{O}\right]$

\begin{tabular}{lllllll}
$\left(\mathrm{mgL}^{-1}\right)$ & $\mathrm{Y}_{\mathrm{P} / \mathrm{S}}^{1}$ & $\mathrm{Y}_{\mathrm{P} / \mathrm{S}}^{2}$ & [Biomass] & $\mathrm{Y}_{\mathrm{P} / \mathrm{X}}$ & $\mathrm{Y}_{\mathrm{X} / \mathrm{S}}$ & $\mathrm{Y}_{\mathrm{H} 2}$ \\
\hline 0.0 & 340 & 391 & 1.34 & 292 & 0.27 & 0.034 \\
50 & 227 & 255 & 1.34 & 190 & 0.27 & 0.022 \\
100 & 227 & 252 & 1.37 & 184 & 0.27 & 0.022 \\
200 & 246 & 270 & 1.39 & 194 & 0.28 & 0.024 \\
500 & 277 & 295 & 1.41 & 209 & 0.28 & 0.026 \\
750 & 233 & 243 & 1.43 & 170 & 0.29 & 0.020 \\
1000 & 183 & 187 & 1.47 & 127 & 0.29 & 0.018 \\
\hline
\end{tabular}

$\mathrm{Y}_{\mathrm{P} / \mathrm{S}}^{1}\left(\mathrm{H}_{2} \mathrm{~mL} \mathrm{~g}^{-1}\right.$ glucose supplied) $\left(\mathrm{mLg}^{-1)}\right), \mathrm{Y}_{\mathrm{P} / \mathrm{S}}^{2}\left(\mathrm{mLg}^{-1}\right)$ (Utilized): $\left(\mathrm{H}_{2} \mathrm{~mL} \mathrm{~g}^{-1}\right.$ glucose utilized), [Biomass] $\left(\mathrm{gL}^{-1}\right)$. Biomass production $\mathrm{g} \mathrm{L}^{-1}$ culture, $\mathrm{Y}_{\mathrm{P} / \mathrm{X}}\left(\mathrm{mLg}^{-1} \mathrm{~L}^{-1}\right)$ : $\left(\mathrm{H}_{2} \mathrm{~mL} \mathrm{~g}^{-1}\right.$ Biomass $\left.\mathrm{L}^{-1}\right), \mathrm{Y}_{\mathrm{X} / \mathrm{S}}$ : (Biomass production per g glucose supplied), $\mathrm{Y}_{\mathrm{H} 2 / \mathrm{s}}$ : (conversion of $\mathrm{H}_{2}$ (ml) to $\mathrm{H}_{2}(\mathrm{~g}) \mathrm{g}^{-1}$ glucose utilized) [Glucose] $.5 \mathrm{gL}^{-1}$, inoculum size $10 \%(\mathrm{v} / \mathrm{v}), \mathrm{I} \mathrm{pH} .7 .0$, Temp $30^{\circ} \mathrm{C}$

Effect of Magnesium: The results described below indicated that the hydrogen production rate and yield was enhanced with the addition of $\mathrm{MgSO}_{4} \cdot 7 \mathrm{H}_{2} \mathrm{O}$ over a range of supplemented medium from $50-500 \mathrm{mgL}^{-1}$ but not with control at $0.0 \mathrm{mgL}^{-1}$, then decreased for further increasing of magnesium concentration with maximum $\mathrm{H}_{2}$ yields of $295 \mathrm{mLg}^{-1}$ glucose utilized, obtained at $\mathrm{MgSO}_{4} \cdot 7 \mathrm{H}_{2} \mathrm{O}$ concentration of $500 \mathrm{mgL}^{-1}$. The results shown in Fig. 7 demonstrate that the maximum $\mathrm{H}_{2}$ productivity of $65 \mathrm{mLL}^{-1} \mathrm{~h}^{-1}$ was obtained at $\mathrm{MgSO}_{4} \cdot 7 \mathrm{H}_{2} \mathrm{O}$ concentration of $500 \mathrm{mgL}^{-1}$ and this was lower than the control of $77.5 \mathrm{mLL}^{-1} \mathrm{~h}^{-1}$ of control at $0.0 \mathrm{mgL}^{-1}$. Table 3 and 4 shows the obtained results from $\mathrm{MgSO}_{4} .7 \mathrm{H}_{2} \mathrm{O}$ addition to formulated medium on hydrogen production by the bacterium species we used in this study.

The results shown in Fig. 6 demonstrated that in supplemented culture, glucose consumed increased from $89 \%$ at $50 \mathrm{mgL}^{-1}$ to $94 \%$ at $500 \mathrm{mgL}^{-1}$ of $\mathrm{MgSO}_{4} \cdot 7 \mathrm{H}_{2} \mathrm{O}$ and to $98 \%$ at $1000 \mathrm{mgL}^{-1}$ but that consumption was used for bacterial growth not for hydrogen production and that clear in Fig. 8, which demonstrated that as the concentration of magnesium increased the final biomass concentration increased with maximum of $1.466 \mathrm{gL}^{-1}$ at $1000 \mathrm{mgL}^{-1}$, suggested that this metal supported the bacterial growth, but not

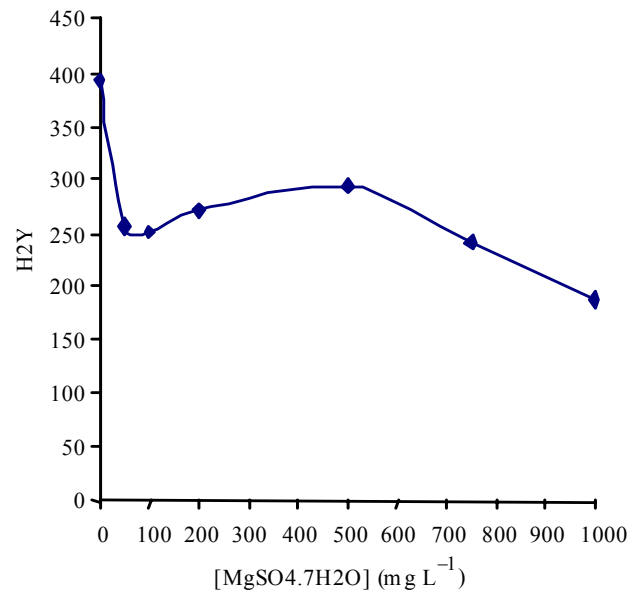

Fig. 5: Effect of $\left[\mathrm{MgSO}_{4} \cdot 7 \mathrm{H}_{2} \mathrm{O}\right]$ addition on. $\mathrm{H}_{2} \mathrm{Y}$ $\left(\mathrm{mLg}^{-1}\right.$ utilized)

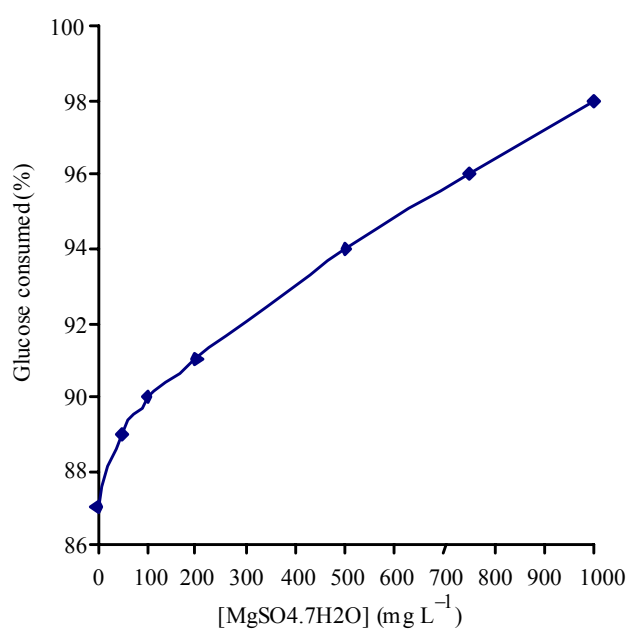

Fig. 6: Effect of $\left[\mathrm{MgSO}_{4} .7 \mathrm{H}_{2} \mathrm{O}\right]$ addition on. Glucose consumption (\%)

hydrogen production by $C$. acetobutylicum NCIMB 13357.

Obtained data shown in Table 3 and 4 were used to calculate different yields like $\mathrm{Y}_{\mathrm{P} / \mathrm{X}}\left(\mathrm{mLg}^{-1} \mathrm{~L}^{-1}\right):\left(\mathrm{H}_{2} \mathrm{~mL}\right.$ $\mathrm{g}^{-1}$ Biomass per $\mathrm{L}$ ), $\mathrm{Y}_{\mathrm{X} / \mathrm{S}}$ : (Biomass production per $\mathrm{g}$ glucose supplied) and $\mathrm{Y}_{\mathrm{H} 2} / \mathrm{s}$ (conversion of $\mathrm{H}_{2}(\mathrm{~mL})$ to $\mathrm{H}_{2}$ (g) per g glucose utilized). These results showed that the presence of magnesium in fermentation medium was adversely affected on hydrogen production but was better for bacterial growth.

Effect of calcium addition: The results shown in Table 5 and 6 indicated that the addition of $\mathrm{CaCl}_{2} \cdot 2 \mathrm{H}_{2} \mathrm{O}$ to fermentation medium didn't enhance the hydrogen 
OnLine J. Biol. Sci., 8 (1): 1-9, 2008

Table 5: Effect of $\mathrm{CaCl}_{2} \cdot 2 \mathrm{H}_{2} \mathrm{O}$ addition to fermentation medium on glucose consumption and hydrogen $\mathrm{H}_{2} \mathrm{P}\left(\mathrm{mL} \mathrm{L}^{-1} \mathrm{~h}^{-1}\right)$ by C. acetobutylicum NCIMB13357

\begin{tabular}{llll}
\hline $\begin{array}{lll}{\left[\mathrm{CaCl}_{2} .2 \mathrm{H} 2 \mathrm{O} .\right]} \\
\left(\mathrm{mgL}^{-1}\right)\end{array}$ & $\mathrm{f} \mathrm{pH}$ & Glucose consumed (\%) & $\mathrm{H}_{2} \mathrm{P}$ \\
\hline 0.0 & 4.45 & 87 & 77.5 \\
10 & 4.46 & 88 & 49 \\
50 & 4.46 & 88 & 50 \\
100 & 4.38 & 90 & 59 \\
150 & 4.39 & 93 & 58 \\
300 & 4.41 & 94 & 52 \\
500 & 4.48 & 96 & 45 \\
\hline
\end{tabular}

[Glucose]: $5 \mathrm{gL}^{-1}$, Inoculum size $10 \%(\mathrm{v} / \mathrm{v}), \mathrm{I} \mathrm{pH} .7 .0$, Temperature $30^{\circ} \mathrm{C}$

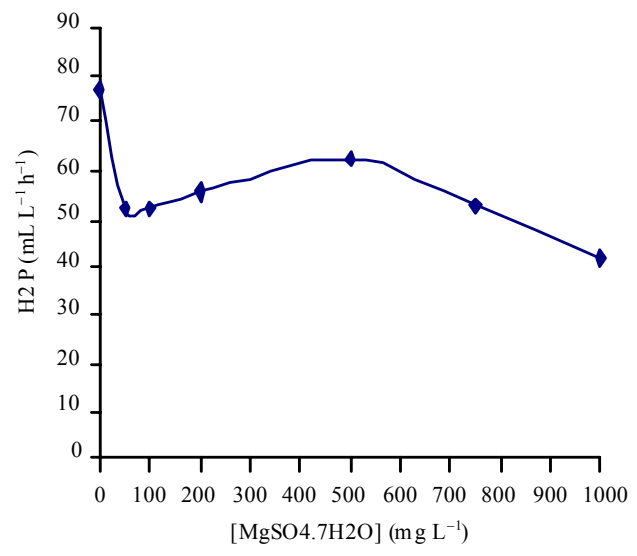

Fig. 7: Effect of $\left[\mathrm{MgSO}_{4} \cdot 7 \mathrm{H}_{2} \mathrm{O}\right]$ addition on $\mathrm{H}_{2} \mathrm{P}$

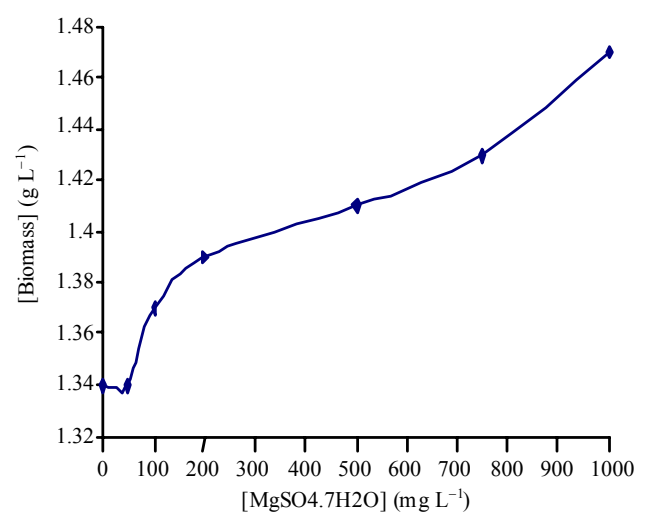

Fig. 8: Effect of $\left[\mathrm{MgSO}_{4} \cdot 7 \mathrm{H}_{2} \mathrm{O}\right]$ addition on. [Biomass]

production compared with the control. The results shown in Fig. 9 and 11, indicated that the addition of $100 \mathrm{mgL}^{-1}$ of $\mathrm{CaCl}_{2} \cdot 2 \mathrm{H}_{2} \mathrm{O}$ to the new medium lead to increase in both $\mathrm{H}_{2}$ production yield and hydrogen productivity over supplemented culture medium but not with control at $0.0 \mathrm{mgL}^{-1}$. The highest hydrogen yield in supplemented culture was $287 \mathrm{mLg}^{-1}$ glucose utilized and that was lower than $391 \mathrm{mLg}^{-1}$ glucose utilized, obtained at $0.0 \mathrm{mgL}^{-1}$. The results shown in
Table 6: Results of $\mathrm{CaCl}_{2} \cdot 2 \mathrm{H}_{2} \mathrm{O}$ addition to fermentation medium on hydrogen production by C.acetobutylicum NCIMB13357

$\left[\mathrm{CaCl}_{2} .2 \mathrm{H}_{2} \mathrm{O}\right.$. $]$

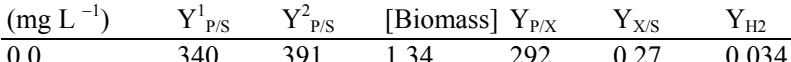

$\begin{array}{lllllll}10 & 214 & 243 & 1.34 & 181 & 0.27 & 0.022\end{array}$

$\begin{array}{lllllll}50 & 221 & 251 & 1.38 & 182 & 0.28 & 0.022\end{array}$

$\begin{array}{lllllll}100 & 258 & 287 & 1.43 & 201 & 0.27 & 0.026\end{array}$

$\begin{array}{lllllll}150 & 172 & 185 & 1.47 & 126 & 0.29 & 0.014\end{array}$

$\begin{array}{lllllll}300 & 147 & 156 & 1.58 & 99 & 0.32 & 0.014\end{array}$

\begin{tabular}{lllllll}
500 & 135 & 141 & 1.73 & 82 & 0.35 & 0.012 \\
\hline$Y^{1}$ &
\end{tabular}

$\mathrm{Y}_{\mathrm{P} / \mathrm{S}}^{1}\left(\mathrm{H}_{2} \mathrm{~mL} \mathrm{~g}^{-1}\right.$ glucose supplied) $\left(\mathrm{mLg}^{-1)}\right), \mathrm{Y}^{2}{ }_{\mathrm{P} / \mathrm{S}}\left(\mathrm{mLg}^{-1}\right)$ (Utilized): $\left(\mathrm{H}_{2} \mathrm{~mL} \mathrm{~g} \mathrm{~g}^{-1}\right.$ glucose utilized), [Biomass] $\left(\mathrm{gL}^{-1}\right)$. Biomass production $\mathrm{g} \mathrm{L}^{-1}$ culture, $\mathrm{Y}_{\mathrm{P} / \mathrm{X}}\left(\mathrm{mLg}^{-1} \mathrm{~L}^{-1}\right)$ : $\left(\mathrm{H}_{2} \mathrm{~mL} \mathrm{~g}^{-1}\right.$ Biomass $\left.\mathrm{L}^{-1}\right), \mathrm{Y}_{\mathrm{X} / \mathrm{S}}$ : (Biomass production per g glucose supplied), $\mathrm{Y}_{\mathrm{H} 2 / \mathrm{s}}$ : (conversion of $\mathrm{H}_{2}$ $(\mathrm{mL})$ to $\mathrm{H}_{2}(\mathrm{~g}) \mathrm{g}^{-1}$ glucose utilized) [Glucose] $.5 \mathrm{gL}^{-1}$, inoculum size $10 \%(\mathrm{v} / \mathrm{v}), \mathrm{I} \mathrm{pH} .7 .0$, Temperature $30^{\circ} \mathrm{C}$

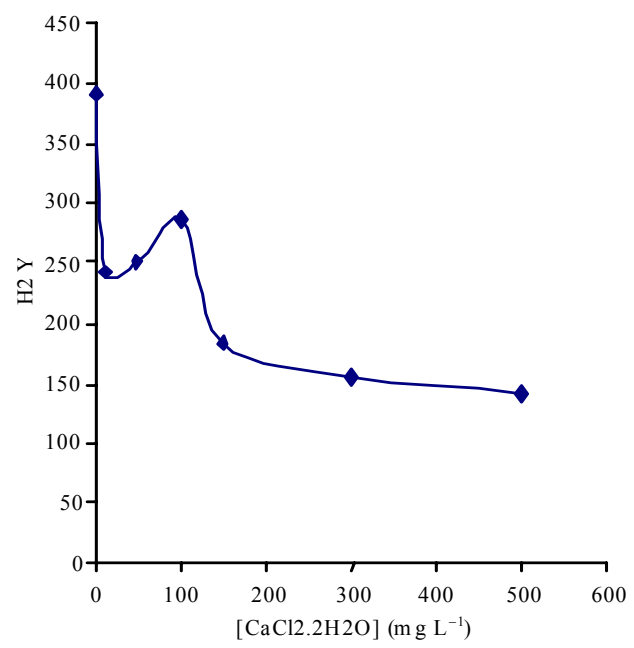

Fig. 9: Effect of $\left[\mathrm{CaCl}_{2} \cdot 2 \mathrm{H}_{2} \mathrm{O}\right]$ addition on. $\mathrm{H}_{2} \mathrm{Y}$ $\left(\mathrm{mLg}^{-1}\right.$ utilized)

Fig. 10 reveal that the highest hydrogen productivity of $59 \mathrm{~mL} \mathrm{~L}^{-1} \mathrm{~h}^{-1}$ obtained at $100 \mathrm{mgL}^{-1}$ of $\mathrm{CaCl}_{2} \cdot 2 \mathrm{H}_{2} \mathrm{O}$ and that was lower than $77.5 \mathrm{~mL} \mathrm{~L}^{-1} \mathrm{~h}^{-1}$ obtained at $0.0 \mathrm{mgL}^{-1}$ and successive increases in $\mathrm{CaCl}_{2} \cdot 2 \mathrm{H}_{2} \mathrm{O}$ lead to decreased in both hydrogen yield and productivity over supplemented culture whereas the results shown in Fig. 10 it might be indicated that the presence of $\mathrm{CaCl}_{2} \cdot 2 \mathrm{H}_{2} \mathrm{O}$ in fermentation medium facilitate the bacterial growth by increasing the percentage of consumed glucose. The results shown in Fig. 12 indicating an excellent utilization efficiency of the carbon source was for bacterial growth and obtained in supplemented culture was at $500 \mathrm{mgL}^{-1}$ of $\mathrm{CaCl}_{2} \cdot 2 \mathrm{H}_{2} \mathrm{O}$ with maximum of $1,73 \mathrm{gL}^{-1}$. Obtained results suggested that calcium is important for bacterial growth but not for hydrogen production by C.acetobutylicum NCIMB13357. 
OnLine J. Biol. Sci., 8 (1): 1-9, 2008

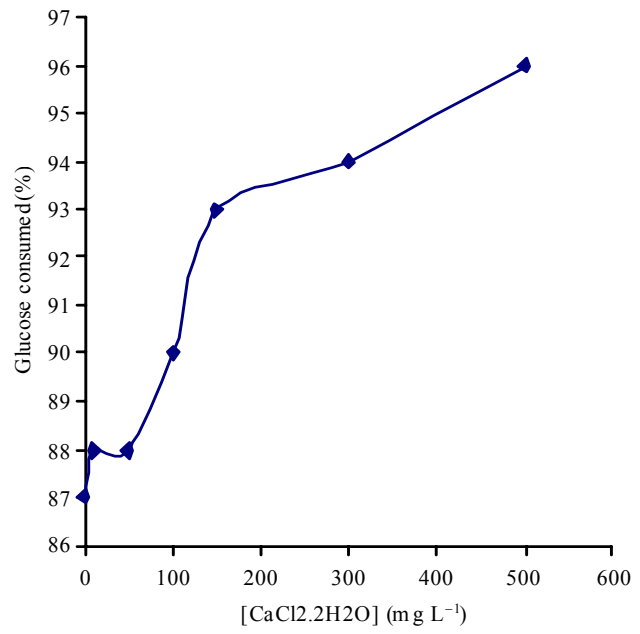

Fig. 10: Effect of $\left[\mathrm{CaCl}_{2} \cdot 2 \mathrm{H}_{2} \mathrm{O}\right]$ addition on. Glucose consumption $(\%)$

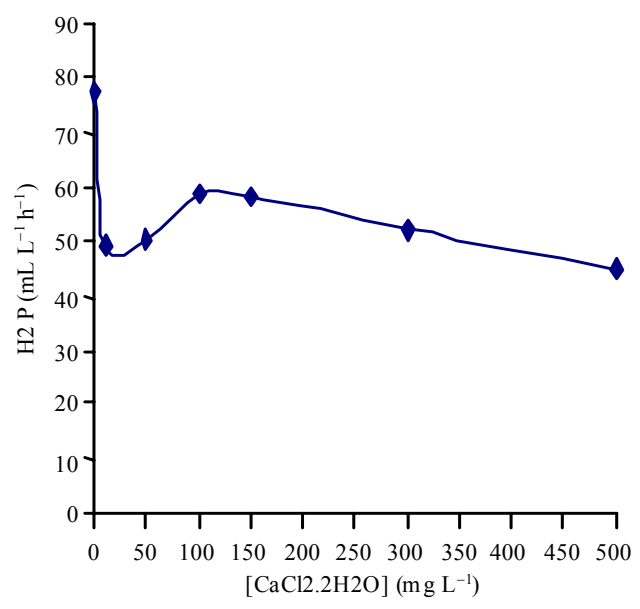

Fig. 11: Effect of $\left[\mathrm{CaCl}_{2} \cdot 2 \mathrm{H}_{2} \mathrm{O}\right]$ addition on $\mathrm{H}_{2} \mathrm{P}$

The results shown in Table 5 and 6 were used to calculate different yields like $\mathrm{Y}_{\mathrm{P} / \mathrm{X}}\left(\mathrm{mLg}^{-1} \mathrm{~L}^{-1}\right)$ : $\left(\mathrm{H}_{2} \mathrm{~mL} \mathrm{~g}^{-1}\right.$ Biomass per $\mathrm{L}$ ), $\mathrm{Y}_{\mathrm{X} / \mathrm{s}}$ : (Biomass production $\mathrm{g}^{-1}$ glucose supplied) and $\mathrm{Y}_{\mathrm{H} 2} / \mathrm{s}$ (conversion of $\mathrm{H}_{2}(\mathrm{~mL})$ to $\mathrm{H}_{2}(\mathrm{~g})$ per g glucose utilized). These results showed that calcium addition to the fermentation medium was inhibited the bacterial production of hydrogen but as well as magnesium addition, it was better for growth suggested that this trace metal affected in such way on the enzyme cascade for hydrogen production even if was in small amount in fermentation medium.

Iron is present in cytochromes and ferridoxins, enzyme cofactor and is important in regulation of secondary metabolism and also plays a role in excretion of primary metabolites ${ }^{[2]}$. All processes of biological

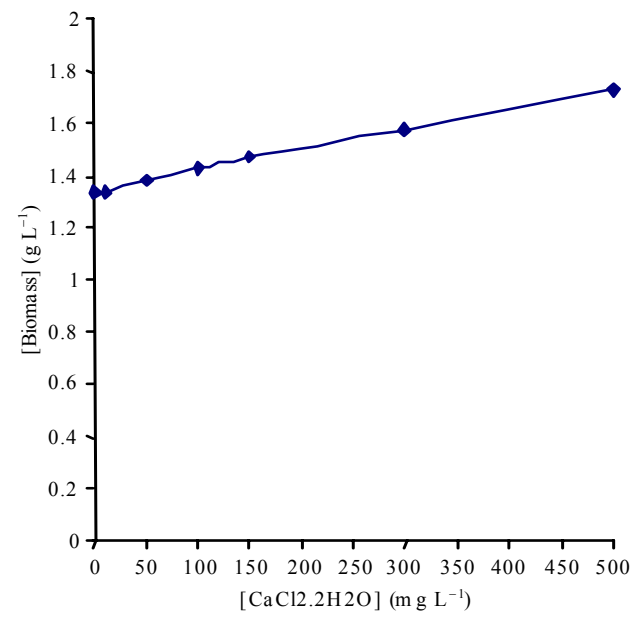

Fig. 12: Effect of $\left[\mathrm{CaCl}_{2} \cdot 2 \mathrm{H}_{2} \mathrm{O}\right]$ addition on. [Biomass], [Glucose]: $5 \mathrm{gL}^{-1}$, inoculum size $10 \%(\mathrm{v} / \mathrm{v}) \mathrm{I} \mathrm{pH}$. 7.0. Temperature $30^{\circ} \mathrm{C}$

hydrogen production are fundamentally dependent upon the presence of hydrogenases. It is hypothetically possible that the quantity or inherent activity of these enzymes could limit the overall process. However, even though the catalytic activity of the various enzymes is enormously different from each other, there is no evidence for the quantity of the hydrogen-producing enzyme being the limiting factor in any system currently under study ${ }^{[6]}$.

There is thus little information on how the iron concentration influences hydrogen production via fermentative bacteria. In this study, in order to convert glucose to high-value hydrogen efficiently, it was investigated that the role of ferrous ion concentration on anaerobic bacteria for hydrogen production. Liu and Shen ${ }^{[7]}$ mentioned that the external iron concentration affect the fermentation of anaerobic bacteria in term of hydrogen production. While others like Dabrock et al. ${ }^{[8]}$ reported that the iron concentration did not have affect on hydrogen production. The result of present study agreed with Peguin and Soucaile ${ }^{[9]}$ they reported that iron concentration above $25 \mu \mathrm{mol} \mathrm{\textrm {L } ^ { - 1 }}$ was none limiting and the metabolism of C. acetobutylicum was normally acidogenic and molecular hydrogen was one of the metabolites and with Schoenhet et al. ${ }^{[10]}$ they demonstrated that growth of C. pasteurianum in batch culture was growth limited when the iron concentration of the medium was less than $10 \mu \mathrm{mol} \mathrm{L} \mathrm{L}^{-1}$, while Dabrock et al. ${ }^{[8]}$ reported that iron concentration up to $10 \mu \mathrm{mol} \mathrm{L}{ }^{-1} 1$ were growth limiting for $C$. pasteurianum but did not cause a decrease of hydrogenase specific activity, a decrease of acid production and an increase 
of solvent production. In our study, the maximum $\mathrm{H}_{2}$ yield was obtained at $25 \mathrm{mgL}^{-1} \mathrm{FeSO}_{4} \cdot 7 \mathrm{H}_{2} \mathrm{O}$. This iron concentration was higher than the 10 and $25 \mu \mathrm{mol} \mathrm{L}^{-1}$ below which the growth of clostridia was limited by the iron concentration ${ }^{[8,10]}$. It may concluded that the effect of the iron concentration on the hydrogen production of clostridia may be caused by not only the iron concentration of the external as limiting factor for the growth but also other environment conditions which iron concentration affected.

In order to find out the conditions that could made the bacterium to be affected by the presence of iron in fermentation media, Junelles et $a l^{[11]}$ pointed out that the hydrogenase specific activity was decreased, carbon and electron flow were affected under iron limitation. Whereas Mongi et al. ${ }^{[12]}$, they stated that at initial $\mathrm{pH}$, the bacterial needed for iron was variant. They reported that at initial $\mathrm{pH}$ of $7.0,1000 \mathrm{mgL}^{-1}$ of $\mathrm{FeSO}_{4} .7 \mathrm{H}_{2} \mathrm{O}$ was sufficient and gave maximum production rate but at initial $\mathrm{pH}$ of 8.5 , the needed was about $25 \mathrm{mgL}^{-1}$ of $\mathrm{FeSO}_{4} .7 \mathrm{H}_{2} \mathrm{O}$, suggested that iron supplementation depend in both initial $\mathrm{pH}$, microorganisms and another factors that affected by iron concentration. Our results regarding the bacterial growth agreed with Junelles et al. ${ }^{[11]}$, they reported that iron limitation affect the growth and the endproducts of fermentation of Clostridium acetobutylicum. They found under iron limitation $\left(0.2 \mathrm{mgL}^{-1}\right)$ (in this study $5 \mathrm{mgL}^{-1}$ ) at a $\mathrm{pH}$ of 4.8, glucose was fermented to butanol as the major fermentation end product and the final conversion yield of glucose into butanol could be increased from $20-30 \%$ by iron limitation. They reported also that the Hydrogenase specific activity was decreased by $40 \%$ and acetoacetate decarboxylase specific activity by $25 \%$ under iron limitation. Concluding that under iron limitation the effect will be on carbon and electron flow in addition to hydrogenase.

Regarding the reported yield, the results of present study was more other reported yield like Lee et al. ${ }^{[13]}$, using sucrose and mixed microorganisms. They found the maximum hydrogen production yield of $131.9 \mathrm{mLg}^{-1}$ sucrose supplied was obtained at the iron concentration of $800 \mathrm{mgL}^{-1} \mathrm{FeCl}_{2}$ and with Zhang and $\mathrm{Shen}^{[14]}$ they reported that $200 \mathrm{mgL}^{-1} \mathrm{FeSO}_{4} \cdot 7 \mathrm{H}_{2} \mathrm{O}$ gave maximum production of hydrogen by mesophilic bacteria. All of these value suggested that the effect depend on the bacterial species and weather pure or mixed culture and also to the medium components and to iron source. For the majority of that researcher they were using mixed culture but for pure culture the conditions is different and also depends on the bacterial species they used. Yang and Shen ${ }^{[2]}$ they were studying the effect of ferrous iron concentration on anaerobic bio-hydrogen production from soluble starch, mentioned that the bio-hydrogen production requires essential micronutrients for bacterial metabolism during fermentation. They found that Sodium, Magnesium, Zinc and Iron are all important trace metals affecting hydrogen production among them iron is one of the important nutrient elements to form hydrogenase or other enzymes which almost all biohydrogen production needs fundamentally. But for the bacterium we used in this study, the addition of iron was enhanced the bacterial productivity of hydrogen and that was concentration dependent and the addition of sodium was affect adversely on both the hydrogen production and bacterial growth. It was reported by Liu and Shen ${ }^{[7]}$ that the lag phase time was affected by the iron concentration when the $\mathrm{Fe}^{+2}$ concentration was less than $20 \mathrm{mgL}^{-1}$ and the maximum hydrogen production increased as the iron concentration increased from 1.2$10 \mathrm{mgL}^{-1}$ then decreased for further increased of iron concentration. Their results showed that $10 \mathrm{mgL}^{-1}$ was optimum for bacteria (mixed) they used to produce hydrogen. For its medium it was found that $25 \mathrm{mgL}^{-1}$ of $\mathrm{FeSO}_{4} .7 \mathrm{H}_{2} \mathrm{O} \approx\left(5 \mathrm{mgL}^{-1}\right.$ iron $)$ was sufficient for C.acetobutylicum NCIMB13357 to maximize the bacterial productivity of hydrogen.

Iron supplementation in hydrogen fermentation media is important because hydrogen producing Clostridia possess the metalloenzymes, hydrogenase and NADH-ferredoxin reductase, which mediate hydrogen formation. Santangelo et al ${ }^{[15]}$ they presented evidence from hydrogenase purified and characterized from two clostridial species showed that these enzymes contain iron clusters and a unique type of $\mathrm{Fe}-\mathrm{S}$ centre termed the $\mathrm{H}_{2}$ cluster. The $\mathrm{H}_{2}$ cluster has been proposed as the site of $\mathrm{H}_{2}$ oxidation and $\mathrm{H}_{2}$ evolution ${ }^{[16]}$. The iron clusters serve to transfer electrons between the hydrogen cluster and the external electron carrier ${ }^{[17]}$. Therefore, it was expected that supplementing with iron would facilitate hydrogenase biosynthesis and hydrogen evolution, whereas iron deprivation could severely affect the enzyme's biosynthesis and function which would then shift the metabolic pathway to alcohol production $^{[18]}$.

The magnesium requirement of bacteria is principally the result of a specific requirement of the ribosomes, it also functions as enzyme cofactor and is present in cell walls and membranes. It was reported by Bahl and Gottschalk ${ }^{[19]}$ that solvent not produced in magnesium limited medium maintained at low $\mathrm{pH}$, whereas Jones and Woods ${ }^{[20]}$ reported that high yield of solvent were obtained in magnesium limited system. Magnesium is one of the most abundant elements 
within microorganism. It is indispensable for many cell reactions and functions. According to literature magnesium ion is an activator of many kinases and synthetases. In cytoplasm there are 10 kinds of enzymes involved in glycolysis and most of these enzymes need magnesium ion as cofactors such as hexokinase, phosphofructokinase, glyceraldehyde-3-phosphate dehydrogenase and enolase, etc. ${ }^{[3]}$.

Magnesium is not only a cofactor of many enzymes but also components of cell wall and cell membrane. The Mg-chelated species of adenine nucleotides are the true substrates for cellular phosphate transfer reactions. Thus, $\mathrm{Mg}$ is a cofactor for many enzymatic reactions, particularly kinases and phosphatases. Glycolysis involves a sequence of reaction converting glucose into pyruvate with the production of ATP. The first step in the glycolysis cascade is to phosphorylate glucose, thus trapping it in the cell. Phosphorylation is achieved in the presence of ATP as the phophate source and a kinase enzyme (hexokinase in the case of this six-carbon sugar). The magnesium interacts with the oxygen of the triphosphate chain, thereby weakening the phosphorous-oxygen bond and making it more susceptible to cleavage reaction required for phosphoryl transfer. Buchanan et al. ${ }^{[21]}$ indicated the addition of $\mathrm{MgSO}_{4} \cdot 7 \mathrm{H}_{2} \mathrm{O}$ resulted in an increase in hydantoinase activity. Our results was disagreed with Mandal and Mandal ${ }^{[22]}$ they reported that magnesium enhanced biogas production from organic wastes for an optimum value of $45 \mathrm{mg}$ for $300 \mathrm{~cm}^{-3}$ slurry but the presence of magnesium inside the fermentation medium was better for bacterial growth not for biogass production and that was clear when it is added even small amount to the fermentation medium suggested that each bacterium species need selected requirements with selected concentration to produce such products with maximum productivity. It was also reported by Mandal and Mandal ${ }^{[22]}$ that pure metallic magnesium was toxic at high concentration for biomethanation process.

The idea of Calcium addition came from the reports showing that addition of divalent metal ions (especially, $\mathrm{Ca}^{+2}$ ) enhanced sludge granulation and cell aggregation.$^{[23]}$. Morgan et al. ${ }^{[24]}$ proposed that $\mathrm{Ca}^{+2}$ is probably a constitution of extracellular polysaccharides known to play a major role in formation of biofilm and thereby enhances cell granulation and settling ability. $\mathrm{Yu}$ et $a .^{[24]}$ also showed that addition of low concentrations of $\mathrm{Ca}^{+2}$ to an UASB reactor enhanced the adsorption, adhesion and multiplication steps of sludge granulation. Calcium is present in bacterial spores and is required as a cofactor (and for stability) of alpha-amaylase and many proteases. It is usually expelled from the cytoplasm and can have an important structural role in the cell proteins and extracellular polymer material, capsule, etc. ${ }^{[3]}$. These observations showed that calcium addition to fermentation medium was important to enhance the bacterial growth and that it was obtained in this study Our results were disagreed with $\mathrm{Yu}$ et al ${ }^{[24]}$ who found that at $\mathrm{Ca} 2+$ concentration of $150-300 \mathrm{mg} \mathrm{L}^{-1}$, hydrogen production by mixed culture was maximum. Thus, addition of $100 \mathrm{mg} \mathrm{L}^{-1}$ of $\mathrm{CaCl}_{2} \cdot 2 \mathrm{H}_{2} \mathrm{O}$ was enough to retain a sufficient amount of biomass but not for biohydrogen production. Addition of calcium to the fermentation medium was adversely affect on bacteria for hydrogen production therefore the new medium it was formulated by using C.acetobutylicum NCIMB13357 for hydrogen production should have only iron as trace element with selected concentration and the others they were tested in this study were better for growth not for hydrogen production

\section{CONCLUSION}

Hydrogen production by C.acetobutylicum NCIMB13357 was enhanced in the presence of iron in fermentation medium and that was concentration dependent, while the addition of $\mathrm{MgSO}_{4} \cdot 7 \mathrm{H}_{2} \mathrm{O}$ or $\mathrm{CaCl}_{2} \cdot 2 \mathrm{H}_{2} \mathrm{O}$ was inhibited the hydrogen production. Maximum hydrogen yield of $408 \mathrm{mLg}^{-1}$ obtained by addition of $25 \mathrm{mgL}^{-1} \mathrm{FeSO}_{4} \cdot 7 \mathrm{H}_{2} \mathrm{O}$. Increasing the iron concentration resulted to reduce the bacterial production of hydrogen. All trace metals tested was better for the bacterial growth with maximum biomass concentration was obtained at maximum concentration of each.

\section{ACKNOWLEDGEMENT}

The author would like the thank Universiti Kebangsaan Malaysia for financial assistance under grant No UKM-OUP-BTK-14/2007

\section{REFERENCES}

1. Tanisho, S., N. Wakoa and Y. Kosako, 1983. Biological hydrogen production by Enterobacter aerogenes. J. Chem. Eng. Jpn., 16: 529-530.

2. Yang, H. and J. Shen, 2006. Effect of ferrous iron concentration on anaerobic bio-hydrogen production from soluble starch. Int. J. Hydrogen Energy,31:2137-2146.

doi:10.1016/j.ijhydene.2006.02.009 
3. Wang, X.J., N.Q. Ren, W.S. Xiang and W.Q. Guo, 2007. Influence of gaseous end-products inhibition and nutrient limitations on the growth and hydrogen production by hydrogen-producing fermentative bacterial B49. Int. J. Hydrogen Energy, 32: 748-754. doi:10.1016/j.ijhydene.2006.08.003

4. Morimoto, M., M. Atsuko, A.A.Y. Atif, M.A. Ngan, A. Fakhrul-Razi, S.E. Iyuke and A.M. Bakir, 2004. Biological production of hydrogen from glucose by natural anaerobic microflora. Int. J. Hydrogen Energy, 29: 709-713. doi:10.1016/j.ijhydene.2003.09.009

5. Miller, G.L., 1959. Use of Dinitrosalicyclic acid reagent for determination of reducing sugar. Anal. Chem. 31: 426-429.

6. Hallenbeck, P.C. and J.R. Benemann, 2002. Biological hydrogen production: fundamentals and limiting processes. Int. J. Hydrogen Energy, 27: 1185-1193.

PII: S0360-3199(02)00131-3

7. Liu, G. and Q. Shen, 2004. Effects of culture and medium conditions on hydrogen production from starch using anaerobic bacteria. J. Biosci. Bioeng., 98: 251-256.

8. Dabrock, B., H. Bahl and G. Gottschalk, 1992. Parameters affecting solvent production by Clostridium pasteurianum. Appl. Environ. Microbiol., 58: 1233-1239.

9. Peguin, S. and P. Soucaille, 1995. Modulation of carbon and electron flow in Clostridium acetobutylicum by iron limitation and methyl viologen addition. Appl. Environ. Microbiol., 61: 403-405.

10. Schonheit, P., A. Brandis and R.K. Thauer, 1979. Ferridoxin degradationin growing Clostridium pasteurianum during period of iron deprivation. Arch. Microbiol., 120: 73-76.

11. Junelles, A., R. Janati-Idrissi, H. Petitdemange and R. Gay, 1988. Iron effect on acetone-butanol fermentation. Curr. Microbiol., 17: 299-303.

12. Mongi, F., C. Edward, H. William, G. Gwang-Hoon and A. Almadidy, 2005. Influence of culture parameters on biological hydrogen production by Clostridium saccharoperbutylacetonicum ATCC 27021. World J. Microbiol. Biotechnol., 21: 855-862.

DOI 10.1007/s11274-004-5972-0

13. Lee, Y., T. Miyahara and T. Noike, 2001. Effect of iron concentration on hydrogen fermentation. Bioresour Technol., 80: 227-231.

PII: SO960-8524(01)00067-0
14. Zhang, Y. and J. Shen, 2005. Effect of temperature and iron concentration on the growth and hydrogen production of mixed bacteria. Int. J. Hydrogen Energy, 31: 441-446. doi:10.1016/j.ijhydene.2005.05.006

15. Santangelo, J.D., P. Durre and D.R. Woods, 1995. Characterization and expression of the hydrogenase-encoding gene from Clostridium acetobutylicum P262. Microbiology, 141: 171-180.

16. Adams, M.W.W., 1987. The mechanisms of H2 activation and $\mathrm{CO}$ binding by hydrogenase II of Clostridium pasteurianum. J. Biolog. Chem., 262: 15045-15064.

17. Adams, M.W.W., 1990. The metabolism of hydrogen by extremely thermophilic, sulfurdependent bacteria. FEMS Microbiol. Rev., 75: 219-238.

198 Bahl, H., M. Gottwald, A. Kuhn, V. Rale, W. andersch and G. Gottschalk, 1986. Nutritional factors affecting the ratio of solvents produced by Clostridium acetobutylicum. Appl. Environ. Microbiol., 52: 169-172.

19. Bahl, H. and G. Gottschalk, 1985. Parameters affecting solvent production by Clostridium acetobutylicum in continuous culture. Biotechnol. Bioeng., 514: 217-223.

20. Jones, D.T. and D.R. Woods, 1986. Acetonebutanol fermentation revisited. Micro Rev., 50: 484-524.

21. Buchanan, K., S.G. Burton, R.A. Dorrington, G.F. Matcher and Z. Skepu, 2001. A novel Pseudomonas putida strain with high levels of hydantoin-converting activity, producing L-amino acids. J. Mole. Catal. B. Enzyme, 11: 397-406.

22. Mandal, T. and N. Mandal, 1998. Biomethanation of some waste materials with pure metallic magnesium catalyst: improved biogas yields. Energy Convers. Mgmt., 39: 1177-1179.

23. Yu, H., J.H. Tay and H. Fang, 2001. The roles of Calcium in sludge granulation during UASB reactor start-up. Water Res., 35: 1052-1060. doi:10.1016/S0043-1354(00)00345-6

24. Morgan, J., L. Evison and C. Forster, 1991. Changes to the microbial ecology in anaerobic digesters treating ice cream wastewater during startup. Water Res., 25: 639-653. 